\title{
MEASURES FOR PREVENTION OF DOMESTIC VIOLENCE AND FOR PROTECTION OF VICTIMS IN SERBIA'S LEGAL SYSTEM WITH SPECIAL REFERENCE TO EMERGENCY MEASURES
}

\author{
Saša M. Marković ${ }^{1}$ \\ University of Criminal Investigation and Police Studies, Belgrade
}

\begin{abstract}
Over the last two decades, combating domestic violence has been one of our country's main goals. Serbia is one of the 12 countries that have ratified the Council of Europe Convention on Prevention and Combating Violence against Women and Domestic Violence (the Istanbul Convention) before its entry into force on August 1, 2014, and as of June 1, 2017 the Law on the Prevention of Domestic Violence (LPDV) has been used in Serbia, which was adopted with the aim of regulating in a general and uniform manner the organization and conduct of state authorities and institutions, thereby enabling the effective prevention of domestic violence and the prompt, timely and effective protection and support for victims of domestic violence. Prescribing emergency measures has radically changed the way the victims of domestic violence are protected. In this paper, we will explore and try to answer several questions: what measures are available to state institutions to prevent violence and protect victims; whether the competent authorities and institutions apply these measures and to what extent; whether it was necessary to introduce urgent measures into our legal system and, finally, whether the activities to combat domestic violence so far produce results, that is, whether this negative social phenomenon is sufficiently suppressed.
\end{abstract}

Keywords: violence, family, urgent measures, protective measures,perpetrator.

$\overline{1 \text { sasamarkovic975} @ g m a i l . c o m ~}$ 


\section{INTRODUCTION}

"Marriage and family as institutions in modern society are of the utmost importance for establishing normal relations in society and for the development of new generations. Although marital and family life fall within the sphere of intimacy that the legislature does not need much to go into, still, some regulatingis necessary above all to protect marriage and the family as institutions of society"(Đorđević, 2009: 93). Family Law (FL), as well as the earlier Law on Marriage and Family Relations (The Law on Marriage and Family Relations, The Official Gazette of the Socialist Republic of Serbia Nos. 22/80, $24 / 84,11 / 88,22 / 93,25 / 93,35 / 94$, $46 / 95,29 / 01)$, oes not define family.It is therefore useful to determine the concept of family in the legal literature as the "fundamental and supreme notion of family law"(Panov, 2012: 33). The Istanbul Convention, like other international human rights treaties, contains no definition of family. According to Article 8 of the European Convention for the Protection of Human Rights and Fundamental Freedoms "everyone is entitled to respect of their private and family life, home and correspondence" ( Convention for the Protection of Human Rights and Fundamental Freedoms) ${ }^{2}$ In its practice, the European Court of Human Rights (ECHR or the European Court of Justice) has "always interpreted the concept of family completely autonomously - independently of the provisions of domestic law - and according to the factual situation in each individual case. Essentially, the right to respect family life includes the right of family members to live together and develop

2 http://www.echr.coe.int/Documents/Convention_ENG.pdf, accessed on February 25, 2019. their relationships. On the other hand, the community of life is not a conditio sine non of family life, which means that family life also exists among family members who live apart"(Draškić, 2011: 50).

In our family law, family can be defined as "a group of persons connected by marriage or extra-marital union and kinship, among whom there are legally established rights and duties, whose disrespect entails certain legal sanctions, or as a set of relatives having mutual rights and duties established by law" (Mladenović, 1981: 46), or "as a group of persons related by marriage and kinship" (Bakić, 1988: 35), or "as a household community of persons connected by marriage and extramarital union and kinship or only by kinship (blood or civil) who have mutual rights and obligations" (Janjić-Komar, Korać, 1996: 41), or "as a community of persons connected by marriage or marital relationship, or kinship, or by the household community of parents, children and other close relatives among whom there are rights and obligations" (Babić, 1999: 30), or as "a community of relatives connected by responsibility for life and mutual well-being" (Janjić-Komar, 2006: 250) or "biological-social community which represents the bridge between the biological world of the individual and the social world of formed personalities"(Draškić, 2011: 49).

However, if we define domestic violence, we will conclude that the family is viewed from a much wider angle than it was stated. The Criminal Code (CC) narrowly defines family members (See the Criminal Code Article 112). The most recently enacted law that addresses 
the issue of domestic violence - LPDV, broadens the definition of domestic violence even in relation to FL, which, in our view, has already broadly defined concept term family member, e.g. "the persons who have been or are still in an emotional or sexual relationship are regarded as family members" (Marković, 2018: 65). It is impossible not to notice that this definition of domestic violence introduces into our legal system, in addition to marital and non-marital family relations, partner relationship as well as economic violence as a form of domestic violence in accordance with Article 3 of the Istanbul Convention (Kolarić, Marković: 2016: 23).

In the text of this paper the author will analyse the strategy of combating domestic violence in the Republic of Serbia, and will try to answer the question how, in what way and by what methods it is possible to improve the effectiveness and efficiency of the internal affairs authorities in order to achieve better results in confronting this negative social phenomenon.

\section{PROTECTIVE MEASURES FOR THE VICTIMS OF VIOLENCE}

Until the beginning of this century, there was no strategy in Serbia to confront domestic violence. As a separate crime, domestic violence was introduced into our country's criminal justice system in 2002. Until then, much other classic incrimination was applied to the perpetrators of such acts, and the fact that violence was committed against a family member could be considered as an aggravating circumstance (Marković, 2015: 109). What we can state with a high degree of certainty is that the phenomenon of increased repression is no longer related to the internal needs of the state, but is increasingly linked to compliance with European standards (Kolarić: 2018: 12). This is the most common reason for reforms beginning in the first decade of the twentieth century until now. Temporamutantur. Times change, and so do we. The claim is true and can be viewed both nationally and internationally (Kolarić: 2016: 641). In addition to the classic repressive measures provided for in the criminal legislation (arrest, detention, custody, imprisonment, etc.), since August 2009, the competent authorities have had a security measure in place to prohibit the offender from approaching and communicating with the injured party (Article 89a CC). However, in the period between 2010 and 2016, only 465 of these security measures were ruled by court rulings (Marković, 2018: 217). Moreover, as of October 1, 2013, by applying the new Criminal Procedure Code generally, the court, as an alternative to ordering detention, was given the opportunity to set a measure during the course of criminal proceedings -restraining order, meeting or communicating with a specific person and visiting certain places. (The Criminal Code, The Official Gazette of the Republic of Serbia, 55/2014).

Previously, as of January 1, 2006, there was a possibility that one or more protection measures provided for in the Family Law could be imposed against a family member of the abuser. Their pur- 
pose was to prevent, by eliminating the circumstances that in the past allowed the perpetrator to commit violence, to prevent new violence in the future, i.e. to effectively protect the victim, their physical and mental integrity, and to give them complete personal security. These measures are very rarely pronounced, regardless of the fact that the guardianship authority has been given the power to file a lawsuit, and the Constitutional jurisdiction has been extended to the public prosecutor despite the repressive and preventive treatment of victims of domestic violence, i.e. they were given the power to file a lawsuit ex officio.

By applying the Law on Prevention of Domestic Violence, as of June 1, 2017, two emergency measures are available to the competent authorities for preventing domestic violence: "a measure of temporary expulsion of the perpetrator from the apartment and a measure of temporarily prohibiting the perpetrator to contact and approach the victim of violence" (Article 17 of theLPDV). Emergency measures may last for up to 32 days. For violation of urgent measures imposed and/or prolonged, the LPDV provided for an offence punishable by imprisonment for up to 60 days (Article 36 of the LPDV). By prescribing this offence, the protective measures provided for in the Misdemeanour Act, the prohibition of access to the injured party, facilities or the place of committing the offense may be fully implemented. It is pronounced to prevent the perpetrator from repeating the offense or to continue threatening the injured party.

From the above we conclude that the Serbian legal system stipulates a number of measures that can be implemented in combating domestic violence, whereby it is up to the competent authorities in each particular case to choose the most appropriate and implement them.

\section{EMERGENCY MEASURES}

By ratifying the Istanbul Convention, our country has committed itself to "take the necessary legislative or other measures and ensure that all relevant authorities assess the risk of mortality, the severity of the situation and the risk of recurrence of violence in order to manage the risk, and, if necessary, provide coordinated protection and support victims" (Article 51 of the Convention). Also, introducing emergency measures into our legal system was one of the obligations.

The risk assessment of the risk of violence by the victim is based "on the information available and shall take place as soon as possible" (Article 16 of the LPDV). For this reason, everyone is obliged to report domestic violence to the police or the public prosecutor, and the public prosecutor is obliged to do this to the police. This means that there are no exceptions, the risk assessment must be done in each reported case, that is, the competent police officer has learned, whether a criminal or misdemeanour charge is filed against the perpetrator, or it can be guessed from the reported event that there is no imminent danger of violence. Risk assessment is also done when family members deny that the complaint is true, but 
also in cases where it is necessary to deprive the perpetrator of their liberty because of the crime committed. The term "as soon as possible" means that the competent police officer carries out the risk assessment as soon as they receive it, regardless of whether or not a possible perpetrator is available to the law enforcement agencies. The main goal is to protect the victim and prevent future violence.

Emergency measures must be imposed whenever a risk assessment indicates that there is an imminent threat of violence in the future. Thereafter, that person may be arrested and/or detained for a crime suspected of having been committed in the past. Therefore, a possible perpetrator may also have the status of a suspect, and the application of the provisions of the LPDV does not present a problem for the implementation of the provisions of the LCP. In doing so, the police and the public prosecutor should take into account the provision of Article 29 of the Constitution of Serbia, where "a person deprived of freedom without a court decision shall be guaranteed to be handed over to the competent court within 48 hours or else there is an obligation of release". This means that no longer than 48 hours may elapse from the moment of bringing a possible perpetrator of domestic violence to their possible surrender to a competent court for custody. Regardless of the fact that detention under LPDV can last up to 8 hours and detention under LPC up to 48 hours, their total duration should not exceed 48 hours (Marković, 2018a: 253).

We have emphasized that LPDV provides for the possibility of imposing and extending two emergency measures, specifying the possibility of simul- taneously imposing both emergency measures in one order. Although there is a possibility in theory, it is difficult to imagine the case in practice of ordering independently a measure to temporarily expel the offender from the apartment. Namely, if we analyse the content and meaning of both urgent measures and the essence of their pronouncement, it is logical that if the perpetrator moves away from the family home, household or apartment where the victim resides, it is necessary to prohibit them the possibility of contact and approach the victim of violence in the family, too. Although legally possible, it would be illogical for the perpetrator to be temporarily expelt from the apartment without any other emergency measure being issued, then approach the victim in the corridor of the apartment building where the victim resides, or in the street going from the apartment to work, or as they go to the store for basic supplies, and commit psychic or physical violence towards them. Such an order would have no effe$\mathrm{ct}$, and it would be ineffective.

"Urgent measures are quasi-sanctions that are substantially identical to criminal law sanctions but are not pronounced in the procedure which precedes them" (Ristivojević: 2018: 150). It should bear in mind that emergency measures are not a punishment for a possible perpetrator. They have a preventive effect because they warn the offender that according to the law it is forbidden to commit violence in the future, and as such they also function to prevent the act for the first time or to repeat acts of violence. Therefore, emergency measures should not be insignificant to the perpetrator, but rather effective and efficient in order to achieve their goal of special and general prevention, and their ultimate goal is to 
protect the family in the broadest sense, as the "basic cell" of human society, but also each of its members individually, especially those that can be classified as particularly vulnerable groups (women, children, the elderly and the ill). Emergency measures protect not only victims of violence but also perpetrators, because by their existence and action they prevent them from acting and repeating violence and consequently protect them from suffering severe legal consequences. Emergency victims should be provided with safety, daily life activities for a certain period of time, relief from trauma and recovery from injuries, but also the time needed to file a lawsuit and bring family protective measures.

A family member exposed to violence suffers the consequences of victimization, or the process of suffering. "Victimization is a process in which someone or something becomes a victim" (Ignjatović, 2015: 16). "Victim, as a phenomenon, is broadly understood to mean a person who is in agony, suffers serious damage, no matter the cause and threat (by this term we mean victims of accidents and natural disasters)" (Ramljak, Simović, 2006: 16). Criminologically and in the criminal-legal sense, the concept of victim is narrowly defined and encompasses the persons whose rights have been directly violated or threatened with the commission of a criminal offense (See: Ignjatović, Simeunović-Patić, 2011: 20). LPDV did not define the concept of a victim of domestic violence, but by its analysis we can conclude that this term is significantly expanded. A victim, in terms of domestic violence as defined in this Law, implies not only a family member who has been subjected to domestic violence (physical, psychologi- cal, sexual or economic) once or more, but also a family member who has not been subjected to violence if the competent police officer identified the risk (danger) of being exposed to domestic violence in the immediate future. This means that the concept of victim also includes the concept of potential (latent) victim. We can say that the goal of preventing victimization in domestic violence is to recognize the dangers of a victimized situation and to discourage a violent family member from committing violence against a vulnerable family member.

A possible perpetrator who is deprived of their liberty (brought and detained) for conducting a preventive procedure, shall be issued emergency measures, following an assessment of the risk that there is an imminent danger of domestic violence, by issuing an order in writing. At this stage of the procedure, during the issuing of the order, and after the risk assessment is completed, the possible perpetrator goes into the phase of the perpetrator of domestic violence, therefore emergency measures are issued to the perpetrator of the violence (Kolarić, Marković, 2018: 56). Bearing in mind that a police order, which is limited to 48 hours, can be extended to another 30 days at the proposal of the public prosecutor in court proceedings, the question arises if this is an administrative decision in which the decision was made in the form of an order. The above procedure of the NPS meets all legal requirements which determine that it is an administrative decision, because an order imposing urgent measures, in accordance with Article 4 of the Law on Administrative Disputes, has all the characteristics of an administrative act of a positive character, which is a formal, constitutive and simple act with 
limited duration to be issued ex officio rather than at the request of the party (Skoko, 2018: 180). It should be emphasized that instantaneous protection of the issued order is not stipulated, the court may only, at the proposal of the public prosecutor, extend the emergency measures issued by the order, but it may not revoke or annul the order (Marković, 2018b: 108). The Supreme Court of Cassation also stated in one of its decisions that an order imposing emergency measures had the character of an administrative act. If we were to accept this statement, the order should be used in Article 141 of the Law on General Administrative Procedure (The Official Gazette of the Republic of Serbia", Nos. 18/2016, 95/2018 (Authentic Interpretation) and it should first and foremost contain the parts and form of the resolution prescribed by the LGAP.
Namely, the LGAP prescribes that "if the decision is not issued by the head of the body but by an authorized official, the introduction shall include his personal name and the legal basis of his authority". Furthermore, such an act should also have a rationale, and the orders issued in the practice of the Ministry of the Interior do not have it in the first two years of implementation of the law. We consider that, although it is clear that an order has the characteristics of an administrative act, it is not, but we can define it only as one specific police authority, whose form is prescribed by the LPDV. Otherwise, if it were taken that the order was an administrative act, it could be annulled in an administrative dispute, which would be conducted in accordance with Article 3 of the Law on Administrative Disputes.

\section{THE MEASURE OF TEMPORARY EXPULSION OF THE PERPETRATOR FROM THE APARTMENT}

The measure of temporary expulsion of the perpetrator from the apartment implies a prohibition on the perpetrator to temporarily access the housing of the victim. So, by apartment we mean any part of the household (room, apartment, house, holiday house, etc.) in which the victim resides. In some cases, the dwelling may include all dwelling facilities in a household (house, shed, garage, barn, etc.). The term "apartment"may be interpreted in its broadest sense, with the measure always in the forefront of the best interests of the victim and our primary goal being how to best protect the victim in the future.

The main concern is whether a competent police officer may expel the offen- der from the apartment of which they are the owner. We can see that in the LPDV the term "eviction" is not used, as defined by the FL, but the "expulsion". In this case, the expulsion is temporary and lasts relatively short - up to 48 hours. The basic question raised here is whether the police can restrict the right of ownership, which is guaranteed by Article 1 of the Additional Protocol No. 1 to the European Convention for the Protection of Human Rights and Fundamental Freedoms. The ECHR has long had the view that the state may restrict this basic human right in order to protect a legitimate general interest. In addition, the ECHR considers that "the state's interference in socio-economic 
issues, such as housing, is very often necessary in order to achieve social justice and public well-being, and that in this area the freedom of assessment that states have in implementing social and economic policies must necessarily be broad".According to the ECHR, "this freedom of assessment must be recognised not only to the domestic legislator, but also to judicial and other authorities, which were invited to interpret and apply the effective legal regulations"(Petrušić, 2007: 61).

Therefore, even when the possible perpatrator is the exclusive owner of the real estate, the order for expulsion from the appartment does not influence the question of ownership. The owner is only temporarily restricted to use their ownership due to the existence of immediate danger of violence. The Constitutional Court, too, has this same view. It is considered that the eviction of a possible perpetrator from an apartment or house of which they are the sole owner did not result in a violation of property rights. Ownership is an absolute right, but the state may stipulate restrictions in the general interest. The measure to expel a potential perpetrator from the apartment is a legitimate restriction on property rights as this protects the general, public interest: protecting the victim against violence. The interference of property rights (and other property rights), i.e. controlling the way of its use is socially justified and allowed, because it respects the requirement of legality - legality (provided by law), and also, seeks to achieve the general, i.e. public interest, which is certainly protection against domestic violence (requirement legitimacy), which is also reflected in the constitutional guarantee of dignity and free development of personality (Article 23 of the Constitution), invi- olability of physical and psychological integrity (Article 25 of the Constitution) and protection of the psychological, physical, economic and any other exploitation of a child (Article 64 paragraph 3 of the Constitution) as well as satisfying the requirement of reasonableness and proportionality. The prescribed emergency measure is only temporary in nature and it does not usurp (revoke) but only restricts some property rights of a family member who is assessed to be likely to commit violence in the immediate future (see more in: Marković, 2018: 263-264). Therefore, by expelling the perpatrator from the apartment the rights of the owner are restricted only by iusutendi, not iusdispenendi (more precisely, the right of disposal) (Panov: 2012: 282).

In Serbia, in 2018, according to the data kept in the unique electronic database of the Ministry of Interior, out of a total of 19,150 orders passed, a measure of temporary expulsion of the perpetrator from the apartment was issued in 8,305 of them. We emphasized that this measure is not generally issued on its own, which means that approximately the same number of orders were issued, which were simultaneously issued both emergency measures. Interestingly, in $10 \%$ of cases (826 times), this emergency measure was imposed on a female family member. It is interesting to note that the largest number of these interim measures were issued at the Police Department of Novi Sad - 848, and then at the Police Directorate of Belgrade 821. The least perpetrators of violence were temporarily removed from the apartment at the Pirot Police Department - 102, and at the Prokuplje Police Department - $103 .^{3}$

3 Data of the MIA of the Republic of Srebia, memo 05.13. No. 235-50619/19-1 as ofJune17,2019. 


\section{THE MEASURE OF TEMPORARY PROHIBITION OF THE PERPETRATOR TO CONTACT THE VICTIM OF VIOLENCE OR TO APPROACH THEM}

This measure has a preventive purpose - to prevent the possibility of committing violence, without having to restrain the victim from performing their daily activities or to disturb their usual life activity, but to prevent opportunities for the perpetrator to commit violence. The measure should allow the victim to free themselves from the fear that a possible perpetrator will suddenly appear near them and attack them. The imposition of a measure is necessary when there is an imminent danger that a potential perpetrator will, for the first time, commit or repeat violence. The conditions for its imposition exist not only when the immediate danger is identified that the victim of violence will suffer violence in the near future, but also when the risk assessment concludes that only approaching the victim or establishing a verbal or non-verbal contact with the potential perpetrator of violence with the victim was a form of psychical violence, since, in certain situations, approaching the victim, calling on the phone, or other means of communication can have psychological consequences.

We see that this emergency measure consists of two prohibitions.

The first prohibition is to prohibit the offender from contacting the victim. The essence of this measure is to prohibit the possible perpetrator from all forms of contact with the victim (including for instance the prohibition of sending e-mails on the Internet, comments on the victim's Facebook profile, etc.). Even if the victim tries to make contact with the perpetrator (e.g. by telephone) for the duration of the prohibition, the perpetrator must not accept the contact (call) but ignore it and inform the police about the event. In such situations, NPS may conduct a procedure where it will conduct a risk assessment and identify the immediate danger of psychological violence in the family by the victim, who may at the same time become a possible perpetrator of domestic violence. The purpose of emergency measures is prevention - prevention of violence, but also protection of the victim. It is argued that communication ban is one possible solution to limit a potential perpetrator from being in a situation of committing violence. In addition to being urgent and timely, the protection of the victim must also be efficient and effective. During emergency measures, it is not enough to adopt a protection plan, and for the state authorities to "boast" on statistical data on the number of emergency measures or individual protection plans, but also that the planned and taken protection measures have an effect on the potential perpetrator to stop the violence if they planned it in the future, that is, to prevent ad hoc situations in which the victim would be at risk. The victim needs to feel safe, to know that they are safe and not to be in danger, that is, the state has done everything in its power to protect them. Therefore, the victim must be interviewed, provided with information and pointed out to the potential risks of violence, while also considering the overall safety of other family members (primarily children) and providing adequate protection. 
The second prohibition is to prohibit the perpetrator from approaching the victim. The essence of this measure is to prevent a possible offender from approaching the victim. The overriding goal of this measure is to prevent physical violence and other types of violence. Namely, the victim should be able to recover psychologically from traumas experienced in the past by a possible perpetrator, and the appearance of the perpetrator of violence in the victim's vicinity is a certain form of psychological violence. In some cases the imposition of this prohibition precludes the commission of sexual and economic violence in the family, especially when it comes to children or the elderly and the sick. Unlike the FL, which provided for similar measures of domestic violence protection for a court to determine the distance that the abuser should not approach the victim, the LPDV did not provide for that the NPS can set a certain distance that the perpetrator should not approach the victim. We believe that a violation of this measure would exist in situations where the person to whom the measure was issued or extended comes into the victim's sight with the intention of disturbing them psychologically. This means that if the perpetrator had met the victim in a public place, and as soon as perpetrator noticed them, the perpetrator would not have violated the emergency measure. These are possible situations, especially in small towns. But if the perpetrator, by knowing the victim's habits, tries to meet them and approach them, e.g. if they would deliberately visit the store every morning at the time the victim goes grocery shopping or near the kindergarten at the time the victim brings the children, then there would be a breach of the emergency measure.

The data from the Ministry of Internal Affairs of the Republic of Serbia show that in 2018 a 19,074 interim injunctions were imposed on the perpetrator to contact and approach a victim of violence, most notably at the Belgrade Police Department - 1,743 and then at the Novi Sad Police Department - 1,731. The least of them were pronounced at the Police Directorate Prokuplje - 249. We see that this measure of pronunciation is slightly less than 2.5 times more than the measure of temporary removal from the apartment.

\section{VIOLATING EMERGENCY MEASURES AND THE PROTECTIVE MEASURE "PROHIBITION ON APPROACHING THE DAMAGED PERSON, THE FACILITIES OR THE SCENE OF THE VIOLATION"}

The Law on Prevention of Domestic Violence in Article 36 provides for a misdemeanor for violations of emergency measures that have been issued or extended, with a sentence of up to 60 days in prison.

"Misdemeanour proceedings in some cases where the legal grounds for bringing under section 190 of the Misdemeanor Act (MA) can be met can be much more effective than other types of court proceedings, with the victim of violence being adequately protected from further violence on the spot. The police must bring the suspect of committing a misdemeanor, together with 
the request for initiating misdemeanor proceedings to the magistrate of the misdemeanor court without delay"(Marković, 2015a: 219), or, if the legal conditions are fulfilled, for a maximum of 24 hours. In this way, we will protect the victim of violence on the spot. The applicant for initiating misdemeanor proceedings shall propose to the court that a verdict be delivered immediately in application of the provisions of Article 308 of the MA. Namely, a conviction can be enforced before its validity, among other things, if the defendant is punished for an offense with serious consequences, and there is a reasonable doubt that they will continue committing the offense, repeat the offense or avoid the enforcement of the imposed sanction. In addition, the provision stipulated in the third paragraph of Article 36 of the LPDV emphasizes that a conviction for the basic form of this offense can be executed before its validity, according to the Misdemeanour Act. This means that, for a violation of an emergency violation that has been issued or prolonged, the court may, at the applicant'smotion, pass a judgment that is enforceable before it becomes final and ruling.

The Misdemeanour Act prescribes a protective measure "prohibition of access to the injured party, facilities or the scene the offense" which is issued "to prevent the perpetrator from repeating the offense or to continue jeopardising the injured party (the victim). This measure is issued at the written request of the applicant for the initiation of the misdemeanor procedure or at the oral request of the injured party pointed out at the hearing during the misdemeanor procedure"(Marković, 2018: 218). The court must decide on the applicant's request.Failing to do so will result in a material breach of the provisions of the misdemeanor procedure (MA, Article 247, paragraph 2).

Thus, by the verdict of the Misdemeanor Court in Požarevac 01.No: 97/18 of 21, November 2018, the perpetrator of the misdemeanor referred to in Article 36, paragraph 1 of the LPDV committed in circumstances (Article 45 of the MA), with the misdemeanor referred to in Article 9, paragraph 1 of the Law on Public Law and Order is a single sentence of 30 days' imprisonment, whereby the court did not decide on the request of the Applicant - Požarevac Police Directorate to impose a protective measure on the perpetrator "prohibiting access to the injured party, objects or place of committing the offense". The verdict was passed as enforceable before its ruling on the applicant's motion, and despite the significant violation of the misdemeanor procedure by the court, it became final (no other motion for protective measure was decided and the applicant did not file a complaint).

In the following example, the defendant A. A. was sentenced to a fine of 20,000 dinars for committing the offense referred to in Article 36, Paragraph 1 of the LPDV. On January 25, 2018, at around 3PM the person mentioned on the same day they violated the emergency measure of temporary expulsion from the apartment, which was issued on January 22 at 3PM and extended by the decision of the Primary Court in Valjevo NP no. 22/18 as of January 23, 2018 , by entering the apartment and taking his personal belongings while the victim's grandmother V.A. was in the apartment. With the same verdict for committing the misdemeanor under Article 8, paragraph 1 of the Law on Public Law and Order (LPLP) the 
offender was fined with 10,000 dinars for forcibly opening the front door, which was locked on January 22 at 3PM when they entered the apartment, using physical force, causing damage to the doorknob whereby causing material damage. The court did not decide on the request of the Ministry of the Interior to impose a protective measure on the defendant "prohibiting access to the injured party, facilities or place of committing the offense". The court also refused to comply with Article 308 (1) (2) of the MA so the judgment did not become enforceable before it became final and ruling. The Misdemeanor Court of Appeal sustained the applicant's appeal (it was well founded), overruled the first instance verdict on the grounds of material breach of the misdemeanor proceedings referred to in Article 264, paragraph 2, item 3 of the MA, and remitted the case for retrial and decision (The judgement of the Misdemeanour Court, Pržn No. 21/18 as of February 2018:2).

The reasoning of the judgment states that one of the reasons for making such a decision is that: "the first-instance court did not consider or decide on the protective measure, or gave reasons whether the conditions for the imposition of the protective measure were fulfilled or not, and for what reason."

It is interesting that the defendant in this case, A.A., also violated the second emergency measure after the first instance verdict - an interim ban on contacting and approaching the victim B. A. (both emergency measures issued and extended by the decision of the Primary Court in Valjevo NP No. 22/18 of 23 January, 2018) by repeatedly contacting the injured party by telephone (as determined by a forensic examination of the injured party V. A.'s cell phone). The perpatrator was brought to a judge of the misdemeanor court under Article 190 of the MA, where he was sentenced to 15 days of imprisonment, which was enforceable immediately pursuant to Article 308 of the MA. (The judgement of the Misdemeanour Court in Valjevo 6Prn. 9/18 as of January :29)

By the same judgment, the applicant's motion to impose a protective measure on the defendant was rejected. The Misdemeanor Court of Appeal sustained the applicant's appeal and reversed the First Instance Verdict, imposing a protective measure on the accused $\mathrm{A}$. A. for a period of six months from the date of enforcement of this verdict. The following was stated in the rationale of the judgment: "Having in mind the established factual situation, as well as the fact that the defendant contacted the injured V. A. herein by the telephone of their sister A. G. within a short time after the extension of the emergency measure and by the decision of the Primary Court in Valjevo, whereby showing perseverance in the conduct of the offense for which they were found responsible for and continued to threaten the injured party, and the identity of the defendant as well as the degree of vulnerability of the injured party, at the request of a court of second instance on the basis of the established condition, it is necessary, as stated by the Applicant in its appeal, to impose a protective measure to the defendant A. A.(...) pursuant to Article 61 of the MA. In view of the aforementioned, this court passed its decision as in the operative part of the judgment, but pursuant to Article 61, paragraph 4 of the MA, the prohibited approach to the injured party measure also includes the prohibition of access to the apartment or household 
during the period for which the prohibition applies."

"The decision of the court imposing a restraining order must include: the time period in which it is enforced, information on the persons the offender may not access, an indication of the facilities that he may not access and at what time, places or locations within which the offender is prohibited." This measure, regardless of whether the offense was committed in a shared dwelling, "also includes a measure prohibiting access to a shared dwelling or household during the period covered by the prohibition. A protective restraining order may be imposed for up to one year, counting from the enforceability of the judgment"(the MA, Article 61). Pursuant to the provisions of the MA, the said measure should run from the day the judgment is enforced, however, if the defendant is sentenced to imprisonment, the measure is not counted for the duration of this measure, as provided for in Article 89a of the CC. Namely, Article 310 of the MA provides for, inter alia, that "imprisonment and protective measures shall be executed in accordance with the law governing the execution of criminal sanctions, unless otherwise provided by this Law". For this reason, we will apply the provision of Article 89a of the CC and the sentence of imprisonment imposed by the judgment will not be counted for the duration of the protective measure. "The injured party shall be notified on the decision of the court imposing a restraining order as well as: the police department competent for the execution of the measur; the competent guardianship authority if the measure relates to a ban on the perpetrator's approach to children, spouse or family members"(the MA, Article 61, Paragraph 6).
If the punished person "who has been issueda restraining order by an enforceable verdict, and who approaches the injured party, premises or the place of the committed offense during the measure or makes contact with the injured party in an unlawful manner or at an inappropriate time, they shall be sanctioned by the regulation providing for the offense for which this measure was issued"(the MA, Article 62). The misdemeanor referred to in Article 36, paragraph 1 of the LPDV is punishable by a sentence of up to 60 days of imprisonment so that an identical sentence can also be imposed for a violation of the protective measure if it has been previously imposed for that offense.

Thus, for committing the offenses referred to in Article 36, paragraph 1 of the LPDV, the defendant S.S. was sentenced to 60 days in prison and given a protective measure of "prohibition toapproach the injured party, premises or the place of committing the offense" for a period of three months, counting from the day the judgment was enforced because the judgment rendered it enforceable even before it became final. Namely, on September 13, 2018, the offender was found by the NPS walking around in the company of their mother, who was the victim of violence, at about 10:20AM, and on September, 7 2018 they were issued and prolonged the emergency measure of temporary restraining order and communication in relation to the victim. On November 26, 2018, after serving a prison sentence, the defendant S.S. was found by the NPS in the family apartment where their mother resides, for the duration of the above protective measure. The offender was remanded to the magistrate after being detained for committing the misdemeanor referred to in Artic- 
le 62 of the MA in relation to Article 36 , paragraph 1 of the LPDV. They were sentenced to 60 days imprisonment and a one-year protective measure "prohibited approach to the injured party, premises or place of the offense".

In the following example, the defendant R. Z. was sentenced to 60 days in prison for violating the protective measure "prohibition of approaching the injured party, premises or the place of committing the offense", which was imposed to them for 10 months for committing the offense referred to in Article 36 of the LPDV. For committing a new offense, in addition to their sentence, the defendant was sentenced to a new protective measure of the same content for a period of 12 months. Namely, they were found by police officers in the family home of the injured - family members, thereby violating the prohibition to approach the victim, that is, the premises - the family house where the injured parties live.

There is a possibility that an emergency measure that has been prolonged may be violated repeatedly, with the offender not available to the police and the court. In that case, a single misdemeanor proceeding will be conducted according to their invention, whereby a "prolonged misdemeanor is committed because the perpetrator with a single intent makes more of the same time-related misdemeanors, which constitute a whole due to the identity of some of the following circumstances: the injured party, the identity of the case the offense, the use of the same situation or a lasting relationship, the unity of the place or space of the offense. In such cases, for offenses referred to in Article 36 section 1 committed in concurrence of offenses, a single sentence of up to 90 days may be imposed." (the MA, Article 46).

There are also situations where an emergency measure that has been prolonged is violated two or more times and individual misdemeanor proceedings are conducted. Namely, the duration of emergency measures that have been extended is 32 days from the moment the order comes, so it may happen that the perpetrator violates an emergency measure, is sentenced, and then again violates the same emergency measure. Thus, the offender G. A. who was sentenced to 10 days in prison on October10, 2018, violated both emergency measures extended by the decision of the Primary Court in Šabac 7.P2N567/18 as of October, 6 2018. After coming out of prison onNovember 2, 2018, the person mentioned violated again both of the emergency measures which were still effective. The new verdict sentenced them to 30 days in prison. In both cases, the applicant did not propose the imposition of a protective measure for the initiation of the misdemeanour proceedings, and therefore the court could not even order it. Although it is evident from this example that the victim will not be protected by the release of the offender and the emergency measures will expire at that moment unless the prosecutor, CSR or other authorized person files a lawsuit to determine the protection measures under the provisions of the MA. Therefore, with the new knowledge of the existence of a threat of domestic violence, the competent police officer must reinitiate a new procedure under the provisions of the LPDV.

In the Republic of Serbia, for the first two years of the application of the LPDV, there were 3,432 violations re- 
ferred to in Article 36, paragraph 1 of this Law, most notably in the Novi Sad Police Administration - 331, in Belgrade 272, in Niš 260, Požarevac 216, in Leskovac 202, and the least in Prokuplje 35 and Prijepolje 39. Most of the persons were convicted in Novi Sad - 282, imprisonment 268, followed by Belgrade - 234, imprisonment 200, Niš -222 , and imprisonment 207. It is interesting that the most severe sentences are pronounced in Belgrade, where 78 sentences were handed down, which are over 30 days, followed byNiš, where there were 73 such sentences, and then in Novi Sad, where 47 of them were pronounced. We see that the strictest criminal policy of the courts is in Niš because $35 \%$ of imprisonment was pronounced for more than 30 days. Most of the protective measures "the prohibition of approaching the injured party, objects or place of committing the offense" were issued in Valjevo 35 (and 93 persons convicted), in Belgrade 16, Novi Sad 6, and in Šabac 1. In other police departments this protective measure was not pronounced.

\section{CONCLUSION}

In order to obtain relevant information, it is necessary to introduce as soon as possible a Central Record of Domestic Violence Cases. The LPDV clearly stipulated this, and sets forth deadlines for this, but Article 32 has not yet been applied. In the first two years of the application of this law, each competent authority has been keeping its records, with the case of domestic violence not having a unique number. A recent survey shows that in the period between June 1,2017, and May 31, 2018, 56.5\% of emergency measures were extended (Bošković, Puhača, 2019:44). According to the data of the Ministry of Internal Affairs for 2018 out of 27,202 pronounced emergency measures, 17,083 or $63 \%$ were extended. However, according to the Republic Public Prosecution, 17,915 motions to extend emergency measures were filed and the court adopted 17,300 and the Ministry of Justice gives similar data as the Republic Public Prosecution. There were 17,783 proceedings for the prevention of domestic violence. If we cross this data, we will come to a different conclusion with respect to investigations using only the data of the MIA, most probably because the decisions on prolonged emergency measures are not kept up to date by the competent police officers in official records. Our 2018 survey shows that for $94 \%$ of the orders, the public prosecution makes a proposal to extend emergency measures, and the court adopts $97 \%$ of the proposals. In conclusion, of the ten emergency measures, nine are extended. This shows us that the police perform a good risk assessment and adequately pronounce emergency measures. In this way, we wanted to point out what kind of mistakes in reaching conclusions could lead to the use of wrong data.

The research we conducted shows us that the protective measure "the prohibition of approaching the injured party, objects or the place of committing the offense" is pronounced the most in the territory of the Kolubara Administrative District; in the territory of the Police Administration of Novi Sad towards 
$2 \%$, whereas in the area of 23 regional police departments this protective measure was not pronounced. The main reason is that authorized applicants do not make such a motion in the request for misdemeanour proceedings. However, what is not taken into account is that by imposing this measure, the victim of violence can be effectively protected for a longer period. The overriding goal of imposing measures should be effectiveness and efficiency in achieving results, i.e. every police officer manager and the competent police officer in their work should think about how to do the right thing in the right way when dealing with the protection against the domestic violence.

Furthermore, we consider it more expedient that seeing that LPDV already regulates criminal proceedings in one part should have also provided the reasons for the obligatory initiation of court proceedings for determining measures of protection under the Family Law. Namely, from the research we conducted, we can conclude that emergency measures have become the dominant measures for the protection of victims of domestic violence, with a large number of recidivist - they are pronounced several times during the year for the same persons and are not accompanied by family protection measures. Moreover, the competent authorities in a negligible number of cases file lawsuits for the determination of protection measures. According to the Ministry of Justice, in 2018, 2,479 lawsuits were filed with the courts in Serbia to determine protection measures, and 17,783 cases for extension of emergency measures were opened. According to the data from the Republic Public Prosecution, in the same period the primary public prosecution filed 297 lawsuits for determining pro- tective measures(out of whichPrimary Public ProsecutionZrenjanin-216, Primary Public ProsecutionNiš -67 and Primary Public Prosecution Šabac - 54 $4^{4}$ as well as 17,915 motions for extending the emergency measures. ${ }^{5}$ This means that in the courts of general jurisdiction this year there have been seven times more proceedings under the provisions of the Law on Prevention of Domestic Violence than under the provisions of the Family Law, and three basic public prosecutors make an exception in filing lawsuits for the determination of protection measures. They filed as many as $2 / 3$ of the total number of lawsuits filed by all public prosecutors. We consider that the main reason for the small number of lawsuits filed, and the uneven practices of public prosecutors, is the same as the reason why the police do not make proposals for the protection measures in misdemeanour proceedings - there is no obligation for the public prosecutors and the guardianship authority, which are alternatively designated for that purpose by law, to file a lawsuit, i.e. they are left to decide whether or not to file a lawsuit. Such is not the case with emergency measures, when the legal requirements are fulfilled, the police have a duty to pronounce them, and the public prosecution submits a motion to the court for extension. That is why, according to the MIA, in 2018, in the reported 27,738 events, 19,150 orders were issued declaring 27,202 emergency measures. Orders were issued in 16,377 cases to males. In addition there were $30,992 \mathrm{ca}$ sualties recorded, of which 29,104 were adults and 1,077 were under the age of 14 at the time of reporting the event.

4 The memo of the Primary Court in Šabac, SU VIII- $42-10 / 2019$ as of June 20,2019.

5 The memo of the Republic Public Prosecution, No. Pi 37/19, as of June 12,2019. 
The largest number of victims is female $-22,212$. Based on the above, we can conclude that the emergency measures have become the dominant way of protecting victims of domestic violence, primarily adults (94\%), most of them female $(72 \%)$, whereby in $85 \%$ the order was made to a possible male offender. These data also confirm to us the results of numerous studies so far that the perpetrators of violence are men and the victims are women, in most cases.

\section{REFERENCES}

1. Babić, I. (1999). Porodično pravo. Beograd: Službeni glasnik.

2. Bakić, V. (1988). Porodično pravo u SFRJ. Beograd: Savremena administracija.

3. Bošković, A. \& Puhača, J. (2019). Analiza praktične primene Zakona o sprečavanju nasilja u porodici, s posebnim osvrtom na primenu hitnih mera. NBP - Žurnal za kriminalistiku i pravo, 24(1), 30-48. doi:10.5937/nabepo24-20343.

4. Council of Europe (1950). Convention for the Protection of Human Rights and Fundamental Freedoms. Rome. Retrived March 21, 2019, from http://www.echr.coe.int/ Documents/Convention_ENG.pdf.

5. Council of Europe (2011). Council of Europe Convention on preventing and combating violence against women and domestic violence. Istanbul. Retrived March 21, 2019, from https://rm.coe.int/168008482e

6. Draškić, M. (2011). Porodično pravo i prava deteta. Univerzitet u Beogradu, Pravni fakultet.

7. Đorđević, Đ. (2009). Krivično pravo: posebni deo. Beograd: Kriminalističko-policijska akademija.

8. Ignjatović, Đ. Simeunović-Patić, B. (2011). Viktimologija. Univerzitet u Beogradu, Pravni fakultet.

9. Ignjatović, Đ. (2015). Kriminologija. Univerzitet u Beogradu, Pravni fakultet.

10. Janjić-Komar, M., Korać, R., Ponjavić,Z. (1996). Porodično pravo. Beograd: No- mos.

11. Janjić-Komar, M. (2006). Roditeljska odgovornost. Novo porodično zakonodavstvo (str. 247-251). Univerzitet u Kragujevcu, Pravni fakultet.

12. Kolarić, D. (2018). Tvrdo jezgro ljudskih prava u praksi Ustavnog suda Srbije i Evropskog suda za ljudska prava u Strazburu: ustavnosudska zaštita u krivičnoj stvari. Revija za krivično pravo i kriminologiju, 56(2), 9-59.

13. Kolarić, D. (2016). Dinamična faza krivičnog zakonodavstva Republike Srbije. Pravni život, 9, 641-669.

14. Kolarić, D., \& Marković, S. (2018). Pojedine nedoumice u primeni Zakona o sprečavanju nasilja u porodici. Anali Pravnog fakulteta u Beogradu, 66(1), 45-71. doi:10.5937/analipfb1801045k

15. Kolarić, D., Marković, S. (2016). Predgovor; Stvarni registar. Zakon o sprečava- nju nasilja u porodici. Beograd: Službeni glasnik. 
16. Krivični zakonik. Službeni glasnik Republike Srbije, br. 85/2005, $88 / 2005,107 / 2005,72 / 2009,111 / 2009,121 / 2012,104 / 2013,108 / 2014,94 / 2016$ i $35 / 19$

17. Marković, S. (2015). Uloga policije u suzbijanju nasilja u porodici u prekršajnom postupku. NBP - Žurnal za kriminalistiku i pravo, 20(2), 211-231. doi:10.5937/ nabepo24-20343.

18. Marković, S. (2018). Sprečavanje i suzbijanje nasilja u porodici. Beograd: Službe- ni glasnik.

19. Marković, S. (2015). Uloga policije u otkrivanju i dokazivanju nasilja u porodici. Doktorski rad, Univerzitet u Beogradu, Pravni fakultet.

20. Marković, S. (2018). Policijska strategija u borbi protiv nasilja u porodici: os- novna kriminalističko-strateška usmerenja u Republici Srbiji. Bezbednost, 60(3),100-116. doi:10.5937/bezbednost1803100m

21. Marković, S. (2018). Pojedina iskustva u primeni Zakona o sprečavanju nasilja u porodici. Organizacija pravosuđa $i$ efikasnost sudske zaštite: evropski standardi $i$ stanje u Srbiji: krivičnopravni aspekt. Beograd: Srpsko udruženje za krivičnopravnu teoriju i praksu.

22. Mladenović, M. (1981). Porodično pravo. Beograd: Privredna štampa.

23. Panov, S. (2012). Porodično pravo. Univerzitet u Beogradu, Pravni fakultet.

24. Petrušić, N. (2007). Međunarodni i domaći pravni okvir ženskih ljudskih prava $i$ rodne ravnopravnosti: kliničko obrazovanje. Niš: Ženski istraživački centar za edukaciju i komunikaciju: Pravni fakultet : Advokatska komora.

25. Prekršajni apelacioni sud, Presuda: Pržn. br. 212/18 od 24. 12.2018.

26. Prekršajni apelacioni sud, Presuda: Pržn. br. 17/18 od 9. 2. 2018.

27. Prekršajni apelacioni sud, Presuda: Pržn. br. 21/18 od 9.2. 2018.

28. Prekršajni sud u Požarevcu, Presuda:Prn. br. 97/18 od 21.11.2018.

29. Prekršajni sud u Valjevu, Presuda: Prn. br. 6/18 od 26. 1.2018.

30. Prekršajni sud u Valjevu, Presuda: Pri. br. 42/18 od 13. 9. 2018.

31. Prekršajni sud u Valjevu, Presuda: Pri. br. 47/18 od 27. 11.2018.

32. Prekršajni sud u Valjevu, Presuda: Pr. br. 173/19 od 15. 1. 2019.

33. Prekršajni sud u Valjevu, Presuda: Prn. 9/18 od 29.1.2018.

34. Prekršajni sud u Šapcu, Presuda: Prn. br. 53/18 od 2. 11.2018.

35. Prekršajni sud u Šapcu, Presuda: Prn. br. 44/18 od 10. 10.2018.

36. Ramljak, A., Simović, M. (2006). Viktimologija. Banja Luka: Panevropski univer- zitet Apeiron.

37. Ristivojević, B. (2018). Da li je Zakon o sprečavanju nasilja u porodici zakazao? Zbornik radova Pravnog fakulteta u Novom Sadu, (1), 137-152.

38. Skoko, D. (2017). Upravnopravna zaštita od nasilja u porodici. Bilten VKS, (3), $170-184$.

39. Sentenca iz presude VKS Kzz 804/2018. (2019). Bilten VKS, (1), 9-10. 
40. Zakon o prekršajima. Službeni glasnik Republike Srbije, br. 65/2013, 13/2016 i 98/2016 (odluka Ustavnog suda).

41. Zakonik o krivičnom postupku. Službeni glasnik Republike Srbije, br. 72/2011, 101/2011, 121/2012, 32/2013, 45/2013, 55/2014 i 35/19..

42. Zakon o sprečavanju nasilja u porodici. Službeni glasnik Republike Srbije, br. $94 / 16$.

43. Zakon o braku i porodičnim odnosima. Službeni glasnik SRS, br. 22/80, 24/84, 11/88, 22/93, 25/93, 35/94, 46/95 i 29/01 (prestao da važi).

44. Ustavni sud, Rešenje IU broj 296/2005 od 9. jula 2009. Službeni glasnik Republike Srbije, br. 101/09. 